\title{
Tropical cyclone effects on vegetation resilience in the Yucatan Peninsula, México, between 2000-2012
}

\author{
Efectos de los ciclones tropicales en la resiliencia de la vegetación \\ en la península de Yucatán, México, entre 2000-2012
}

\author{
Gabriel Sánchez-Rivera ${ }^{1^{*}}$ (10) \\ Leticia Gómez-Mendoza²
}

\begin{abstract}
The resilience capacity of vegetation in the Yucatan Peninsula is influenced by the winds and rains of tropical cyclones. There are no recent long-term studies on cyclonic impacts on natural vegetation in the region despite their significant effects on infrastructure and biodiversity. The objective of this study was to identify the area impacted by 21 tropical cyclones between 2000 and 2012 and to quantify the recovery capacity of the vegetation by using standardized anomalies of the normalized vegetation index (aNDVI). MODIS images from NASA's "Terra and Aqua" satellites were used to calculate the damaged areas by analyzing the frequency of pixels corresponding to each type of vegetation per impact zone. The results showed that in $67 \%$ of the tropical cyclones, the impacts on vegetation were negative -a decrease in aNDVI — but in 33\% of the cyclones, positive effects were recorded —an increase in aNDVIThe lapse rate of vegetation recovery varied in $52 \%$ of the cases; vegetation recovered between two and three weeks after each cyclonic event, while $38 \%$ of the cases recovered within four to five weeks of the cyclone landfall. Tropical forests suffered the most significant effects, followed by hydrophilic vegetation. The most destructive hurricanes were Emily, Wilma, and Dean. The rate of recovery laps ranged from 4 to 10 weeks after the hurricane hit. The results could improve assessments of vegetation vulnerability against severe hydrometeorological events and establish priority zones for prompt inspection.
\end{abstract}

Keywords: ecological resilience; tropical cyclones; NDVI anomalies; Yucatán Peninsula.

\section{Resumen}

La capacidad de resiliencia de la vegetación en la Península de Yucatán está influenciada por los vientos y las lluvias de ciclones tropicales. No existen estudios recientes a largo plazo relacionados con los impactos ciclónicos sobre la vegetación natural de la región a pesar de sus grandes efectos en la infraestructura y la biodiversidad. El objetivo de este estudio fue identificar el área impactada por 21 ciclones tropicales entre 2000-2012 y cuantificar la capacidad de recuperación de la vegetación mediante el uso de anomalías estandarizadas del índice de vegetación normalizado (aNDVI). Se utilizaron imágenes MODIS de los satélites "Terra y Aqua" de la NASA para calcular las áreas dañadas considerando la frecuencia del número de píxeles correspondientes a cada tipo de vegetación por zona de impacto. Los resultados mostraron que en el $67 \%$ de los ciclones tropicales los impactos en la vegetación fueron negativos — disminución en aNDVI- pero en el 33\% de los ciclones tropicales se encontraron impactos positivos —aumento en

\footnotetext{
1 Division of Sustainable Development, University of Quintana Roo, Mexico. grivera@uqroo.edu.mx. Corresponding author

2 College of Geography. School of Philosophy and Literature. National Autonomous University of Mexico, Mexico. gomez.leticia852@ gmail.com
} 
aNDVI-. El lapso de recuperación de la vegetación varió. En el 52\% de los casos, la vegetación mostró recuperación entre dos o tres semanas después de cada evento ciclónico, mientras que en el 38\% de los casos se produjo dentro de las cuatro a cinco semanas posteriores a la llegada del ciclón. Los bosques tropicales sufrieron los efectos más significativos seguidos de la vegetación hidrófila. Los huracanes más destructivos fueron Emily, Wilma y Dean. El período de recuperación varió de 4 a 10 semanas después del cada huracán. Los resultados podrían mejorar las evaluaciones de la vulnerabilidad de la vegetación frente a eventos hidrometeorológicos severos y establecer zonas prioritarias para su pronta inspección.

Palabras clave: resiliencia ecológica; ciclones tropicales; anomalías del NDVI; península de Yucatán.

\section{Introduction}

Resilience and recovery are two crucial concepts in the ecological service literature. Holling (1996) defines ecological resilience as the magnitude of the disturbance that a system can absorb before changing its structure by modifying the variables and processes that control its behavior. Oliver et al. (2016) argued that the concept of ecological resilience recognized the existence of multiple stable states and their ability to resist "regime changes" between alternate states. Tropical cyclones are considered regime changes in ecosystems. Vegetation recovery after the strike of a hurricane is essential to maintaining ecological protection services. To understand resistance and resilience, it is necessary to perform studies from different spatiotemporal and dimensional scales to grasp the significance of the processes that lead to an ecosystem suffering the impairment of its dynamics and functional performance (Ghazoul \& Chazdon, 2017).

Mexico receives direct impacts from tropical cyclones because it is located between two cyclogenetic zones: the Northeast Pacific and the Northern Atlantic (Rosengaus-Moshinsky, 2010). The National Oceanic and Atmospheric Administration (NOAA) estimated an annual average of 12.1 tropical storms and 6.4 hurricanes in the Atlantic basin and 16.6 tropical storms and 8.9 hurricanes in the northeast and central Pacific (NOAA, 2014). During the second half of the 20th century, the most intense hurricanes, categories 4 or 5 according to the Saffir-Simpson scale, occurred in the Yucatan Peninsula region, mainly in Quintana Roo state, since it is on the track of Atlantic cyclonic systems (Ihl \& Frausto-Martínez, 2014).

High-intensity winds and heavy rains associated with cyclones can cause disasters in regions with human settlements, such as damage to infrastructure, cultivation areas, and human losses and injuries (Rosengaus-Moshinsky, Jiménez-Espinosa, \& Vázquez-Conde, 2002). In addition, these extreme weather systems also affect the natural environment by altering biodiversity patterns and ecosystem services (Solow, 2017; Van de Pol, Jenouvrier, Cornelissen, \& Visser, 2017). In contrast, hurricanes can create favorable conditions for the regeneration of certain species capable of withstanding hurricane-force winds (Snook, 1993; Vink \& Ahsan, 2018).

Ecosystem services depend directly on the conservation status of the vegetation cover. In the Yucatan Peninsula case, vegetation is mainly represented by tropical rainforests; medium and low deciduous forests are located predominantly in Yucatan state, while tall and medium subevergreen primarily occur in Campeche and Quintana Roo states (Sánchez Aguilar \& Rebollar Domínguez, 2016). However, this type of forest suffers from deforestation and illegal logging (Rebollar, De la Paz-Pérez Olvera, \& Quintanar, 1993) and land-use change to urban areas or cattle (Rosengaus-Moshinsky, 2010). Additionally, vulnerability to tropical cyclones is increased due to low relief, which does not decrease wind flow (Boose, Foster, \& Hall, 2003).

The multitemporal analysis of the impacts of cyclones on vegetation is relevant. According to Buma and Wessman (2011), much of the knowledge about vegetation resilience comes from the investigation of disturbances caused by singular events. Various studies on the Pacific coast of Mexico consider tropical cyclones to be one of the prime causes of disturbances in ecosystems (Bhaskar et al., 2018; Tapia-Palacios et al., 2018). Some studies, such as those of Parker, Martínez-Yrízar, Álvarez-Yépiz, Maass, \& Araiza (2018), quantified the change in vegetation by applying the normalized vegetation index (NDVI) and LIDAR images (laser imaging detection and ranging) after the passage of hurricanes Jova (2011) and Patricia (2016). Examples of large-scale studies applying sampling techniques are those of Jimenez-Rodríguez et al. (2018), who identified the relationship between the structure and composition of the forest, recovery capacity, and damage magnitude.

Another example is provided Martínez-Yrízar et al. (2018), who compared two hurricanes of distinct categories to estimate the Chamela dry forest litter production by analyzing the ecosystem's short-term 
response. However, most of the research has focused on the evaluation a single cyclone's effects on vegetation or the comparison of just a few cyclonic events. Long-term analysis of hurricane impact on vegetation in the Yucatan Peninsula is still scarce.

To understand the dynamics of the ecosystem recovery processes, it is necessary to have data before and after each extreme event. However, the field samples and measurements may be restricted due to damage and restricted access to sites (Holm et al., 2017). Therefore, indirect methods, such as satellite-derived images, present an alternative to estimating the impacts' spatiotemporal scope. Remote sensing techniques with products designed to record different electromagnetic spectrum ranges have allowed the algebraic combination of spectral bands to detect vegetation cover variations (called "green indexes"). Yengoh et al. (2016) argued that the NVDI is the most widely used technique in detecting spatiotemporal vegetation changes. As Ghazoul \& Chazdon (2017) indicated, the implementation of the NDVI on a smaller scale allows the identification of the landscape's degradation and recovery through indirect measures of treetop or forest cover densities.

The objectives of this work are a) to estimate the impact area of 21 tropical cyclones that hit the Yucatan Peninsula between 2000-2012; b) to estimate the vegetation recovery capacity after the landfall of each cyclone through the NDVI anomaly value; and c) to identify whether the effects of cyclones on ecosystems are related to their trajectory, their category, or their landfall.

\section{Methodology}

\subsection{Study area}

This study considers the Yucatan Peninsula physiographic province (INEGI, National Institute of Geography and Statistics, 2001). The Yucatan Peninsula is located between $17.8^{\circ}$ and $21.6^{\circ}$ north latitude and $86.7^{\circ}$ and $92.4^{\circ}$ west longitude (Figure 1 ) and has an extension of $126,547.38 \mathrm{~km}^{2}$ and a vegetation cover of $98 \%$. It is characterized by a large karst platform and low altitude $(0-300 \mathrm{~m})$.

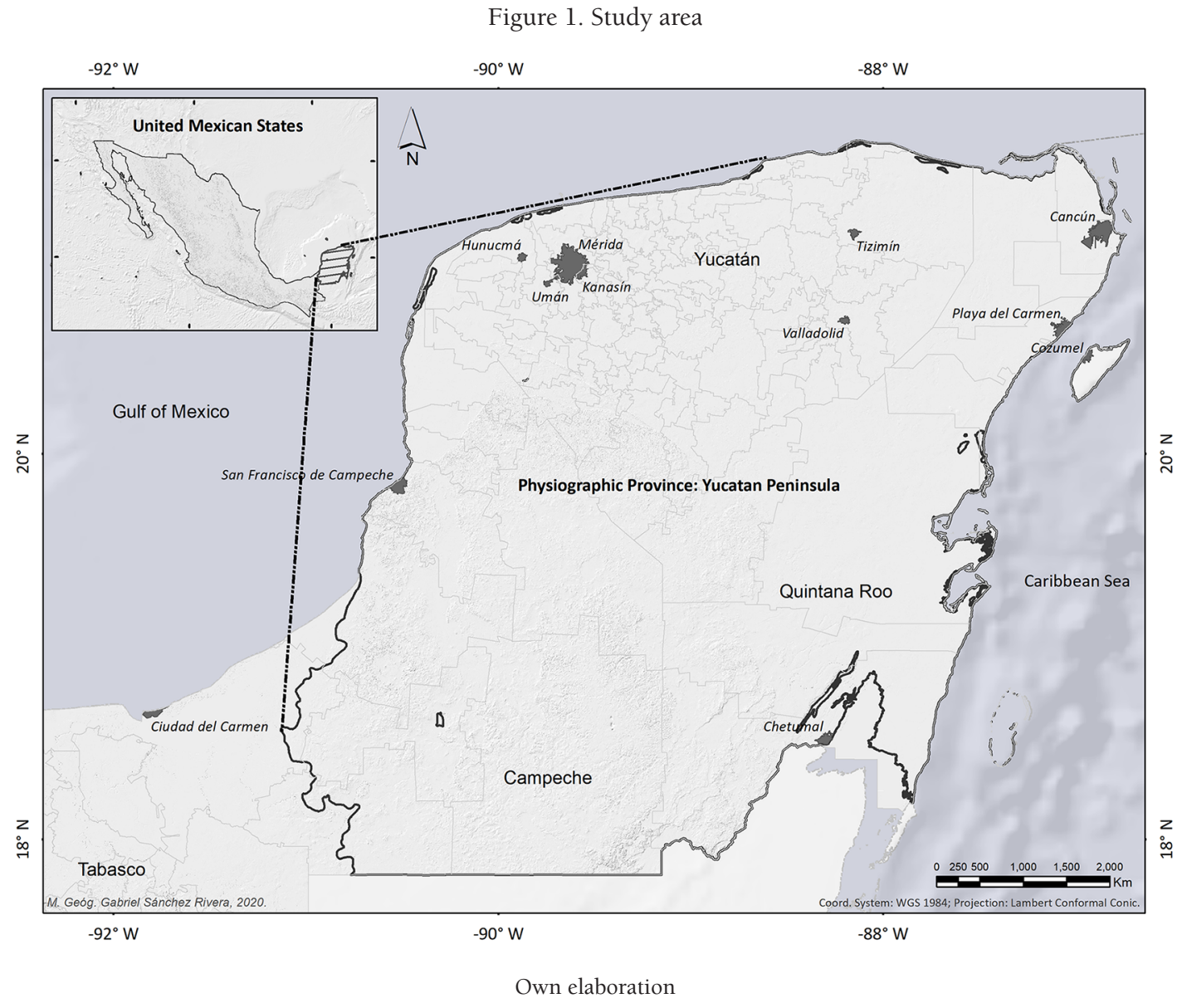


The region largely consists of two climates: a warm wet climate with an average temperature between 24 and $26^{\circ} \mathrm{C}$ distributed from north to south, and a very warm climate with temperatures between 26 and $28^{\circ} \mathrm{C}$ toward the state of Campeche. The hurricane season occurs from June to November. May to October is the rainy season, with the highest rainfall (> $200 \mathrm{~mm}$ ) in September due to the presence of tropical cyclones.

\subsection{Data}

Data and supplies for the research development came from the following free remote sensing databases and cartographic repositories: a) Cyclone trajectory from the library of the Best Track Archive for Climate Stewardship (IBTrACS, 2016) version "v03r09" by NOAA for the period 2000-2012, b) Vegetation types from the National Continuum of Land Use and Vegetation (LUV), scale 1: 250,000 series IV (INEGI, 2009), c) NDVI time series from the data library of the Research Institute for Climate and Society (IRI, 2017) of the USGS LandDAAC MODIS version_005 Southern North America series, with a temporal resolution of "16-day composites", at a spatial resolution of $250 \mathrm{~m} /$ pixel (Huete et al., 2002). Both cartographic products and satellite images were processed using map algebra functions integrated with the geographic information system (GIS) ArcGIS 10.3.

An intersection geoprocess was used on a map overlapping the vector layers of the cyclone tracks formed into the North Atlantic basin and the peninsula polygon to identify the 21 cyclones that made landfall on the Yucatan Peninsula between 2000 and 2012. To simplify vegetation types, we performed cartographic reclassification from LUV to eliminate the polygons corresponding to the following categories: human settlements, bodies of water, other vegetation, and without vegetation. The remaining polygons were merged to create a new classification integrated only by tropical forest, grassland, farming, and hydrophilic vegetation.

The condition of vegetation is characterized at any given time by the historical mean of the period, in such a way that positive values represent an increase in photosynthetic activity — surplus-, while negative values are stated lower than expected by the mean - deficit-, where the "normal condition" is given by amounts between -1 and +1 . NDVI time series integrated by 16-day composites overlapped with the Yucatan Peninsula polygon. The annual NDVI cycle was made up of twenty-three 16-day composites, resulting in 299 images for the 2000-2012 periods. For identification, each composite was chronologically numbered from 1 to 23 per year — composite number-year-. Data were available from 4-2003 (18 Feb - 4 Mar) to 23-2012 (18-31 Dec), and composites 13-2003 (12 - 27 Jul), 13-2008 (11 - 26 Jul), and 20-2010 (1 - 16 Sept) were reported as missing by IRI (2017).

The NDVI was calculated as the normalized difference of two spectral bands - red and near-infrared-, whose standardized variation was within the range of -1 to +1 ; the mathematical function for the computation is shown in Equation 1:

Equation 1. NDVI determination

$$
N D V I=\frac{(N I R-R)}{(N I R+R)} \quad \begin{aligned}
& \text { Where: } N D V I=\text { Normalized vegetation index; } \\
& N I R=\text { Near infrared, and } R=\text { Red }
\end{aligned}
$$

\subsection{Methods}

The study had two analysis stages: a) estimation of the cyclone impact area and b) estimation of the vegetation resilience after every cyclone.

\subsubsection{Estimation of the cyclone impact area}

To distinguish between seasonal phenological changes in vegetation and those associated with a tropical cyclone passage, we defined three "neighborhoods ( $\mathrm{Nh}$ )" (buffer areas) for each cyclone track: Nh-100 km, Nh-200 km, and Nh-300 km. For the neighborhoods for each cyclonic trajectory, we considered the impact zone (strike zone), described by the National Hurricane Center (NHC, 2019). According to the track, the strike zone represents the typical extension of the hurricane winds category, centered on the hurricane's eye (Figure 2). 
Figure 2. a) Impact zone (strike zone), b) Delimitation of neighborhoods

a)

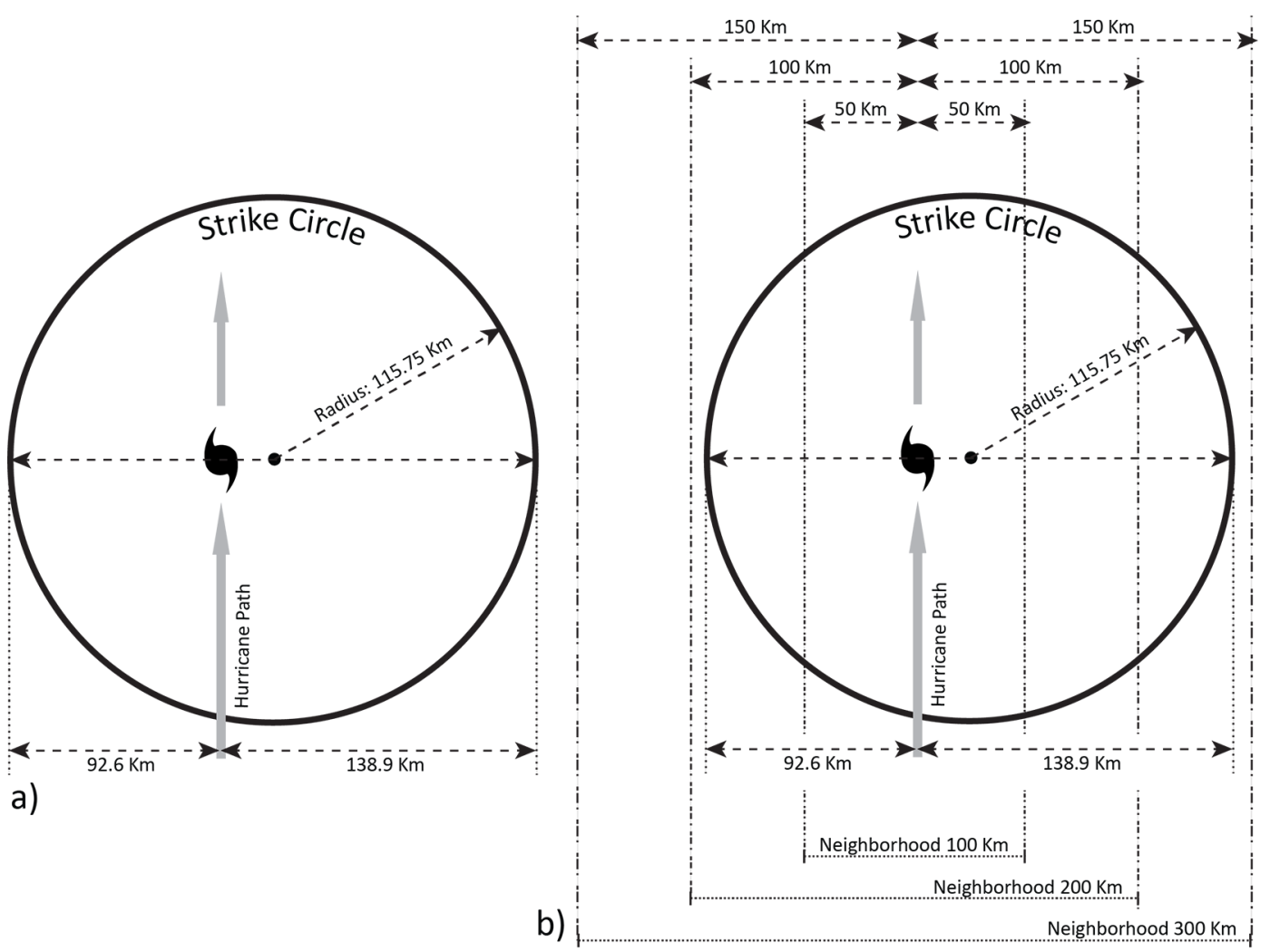

Source: a) NHC (2019); b) Own elaboration

\subsubsection{NDVI anomalies (aNDVI)}

To determine the annual variation of vegetation phenology in the NDVI values from the sudden changes associated with a cyclonic path, we calculated the NDVI anomalies (aNDVI), where aNDVI is the difference between a sample value of a 16-day NDVI composite and the average NDVI value for the study period. The concept of climatic anomalies proposed by Wilks (2011) was adapted to calculate the aNDVI. The aNDVI is used widely for different purposes in agriculture, pests, forest management, water deficit, and drought assessment, allowing measuring changes in terms of the photosynthetic activity of vegetation — greenery — in its interannual shift (Aboud, Bias, Brites, \& Santos, 2018; Meroni, Fasbender, Rembold, Atzberger, \& Klisch, 2019; Nanzad et al., 2019; Zewdie \& Csaplovics, 2015). The average and extreme values of aNDVI were quantified under the assumption that, due to the seasonal variation in events, anomalies provide more information about the magnitude of data series values by removing the influences of dispersion (Wilks, 2011). The adjusted mathematical expression to compute the aNDVI values is as follows (Equation 2):

\section{Equation 2. aNDVI determination}

$$
a N D V I=\frac{(N D V I x-N D V I x p)}{N D V I x S}
$$

where: $a N D V I=$ anomaly normalized NDVI; NDVIx $=$ NDVI date $x ;$ NDVIxp $=$ NDVI sample average; and NDVIxs $=$ NDVI sample standard deviation.

To calculate the aNDVI, we applied Equation 2 at the pixel level for each annual set of images. The operation was performed using the ArcGIS "Cell Statistics" function. The NDVI and aNDVI were plotted to compare the landfalling cyclones with the time series to highlight observed phenological variations associated with cyclonic events, given that the interannual variation in NDVI is an indicator of vegetation phenology (Gómez-Mendoza, 2007). 


\subsubsection{Resilience estimation}

The estimation of ecological resilience capacity (Holling, 1996) was obtained by calculating the recovery rates of photosynthetic activity measured as a function of the aNDVI in periods of 4 weeks after each tropical cyclone had landfall (Rouse, Haas, Schell, \& Deering, 1973). The damaged area for each composite was calculated through the frequency of pixels concerning each neighborhood's vegetation type. We defined the impacts caused by each cyclone in five stages:

a. For each cyclone, six composites were selected: one prior -16 days before-, one during the event, and four after landfalling — 84 days later-.

b. We recalculated the aNDVI values for each of the three cyclone-neighborhood combinations for each of the six composites selected per event. This operation was replicated for every one of the 21 cyclones. Subsequently, the results of each composite were subclassified by each vegetation type.

c. The areas damaged by cyclones were estimated in percentages divided into two classes: moderate and extreme deficits.

d. The estimation of the aNDVI per vegetation type was processed from the earlier step's images using the ArcGIS "Zonal Histogram" function.

e. The weekly recovery rates were obtained, calculating the differences in aNDVI values between the previous composite concerning cyclone landfall and the subsequent composites.

Map algebra processing and operations were performed with Python programming language at a pixel resolution.

The impacts of each cyclone were classified using the IRI, UNESCO, FAO, and Ministry of Agriculture of Chile \& Center Water for Arid Lands (2021) scale of interpretation of aNDVI values. This scale classifies the data dispersion around the mean value, measured in terms of the standard deviation, where values between - 1 and 1 represent normal conditions, values greater than 2 represent moderate and extreme surplus, and less than -2 represent moderate deficit and extreme (Table 1).

Table 1. aNDVI classification

\begin{tabular}{|c|c|c|}
\hline Scale & Class & Rank \\
\hline & Extreme deficit & $<-3$ \\
\hline & Moderate deficit & -3 to -2 \\
\hline & Slight deficit & -2 to -1 \\
\hline & Normal & -1 to 1 \\
\hline & Slight surplus & 1 to 2 \\
\hline & Moderate surplus & 2 to 3 \\
\hline & Extreme surplus & $>3$ \\
\hline
\end{tabular}

Source: Adapted from IRI, UNESCO, FAO, Ministry of Agriculture of Chile \& Center Water for Arid Lands (2021). Own elaboration

\subsubsection{Statistical analysis}

We applied a multiple-correlation model and a linear regression analysis to identify the impact of cyclonic events on the aNDVI. The variables considered to carry out the multiple correlations were cyclone category —-Saffir-Simpson scale—, maximum sustained winds $[\mathrm{km} / \mathrm{h}]$, distance traveled on land $[\mathrm{km}]$, maximum damaged area [\%], a maximum difference of aNDVI [\%], and recovery rate [number of composites]. We analyzed data through a linear regression method. Three pairs of variables were selected: a) maximum damaged area [\%] vs. maximum increase or decrease [\%] in aNDVI; b) maximum sustained winds [km/h] vs. maximum increase or decrease [\%] in aNDVI; and c) distance traveled [km] vs. maximum increase or decrease [\%] in aNDVI. The earlier three cases included the cyclone category as an additional reference variable. 


\section{Results}

\subsection{Tropical cyclones}

Thirteen of the twenty-one cyclones studied in the period 2000-2012 reached the Saffir-Simpson hurricane category, and only five of them maintained that category when landing: Isidore (2002), Emily (2005), Wilma (2005), Dean (2007), and Ernesto (2012). Hurricane Dean (2007) stands out for being the only cyclone to maintain the H5 category in contact with Quintana Roo's coast (Table 2).

Table 2. Cyclones that landfall the Yucatan Peninsula (2000-2012)

\begin{tabular}{|c|c|c|c|c|c|c|c|c|c|}
\hline & \multicolumn{5}{|c|}{ General } & \multicolumn{4}{|c|}{ Landfall } \\
\hline Cyclone & Max. S.S. & Start Time (UTC) & End Time (UTC) & $\begin{array}{c}\text { Max. } \\
\text { Winds } \\
{[\mathrm{Km} / \mathrm{h}]}\end{array}$ & $\begin{array}{c}\text { Track } \\
\text { length } \\
{[\mathrm{km}]}\end{array}$ & $\begin{array}{l}\text { Max. S.S. } \\
\text { on Land }\end{array}$ & $\begin{array}{l}\text { Landfall Time } \\
\text { (UTC) }\end{array}$ & $\begin{array}{c}\text { Max. } \\
\text { Winds } \\
{[\mathrm{Km} / \mathrm{h}]}\end{array}$ & $\begin{array}{c}\text { Track } \\
\text { length } \\
{[\mathrm{km}]}\end{array}$ \\
\hline Gordon & HI & 14/09/2000 12:00 & $21 / 09 / 200000: 00$ & 130 & $3,884.12$ & TD & 17/09/2000 06:00 & 46 & 275.15 \\
\hline Keith & $\mathrm{H} 4$ & 28/09/2000 18:00 & 06/10/2000 06:00 & 222 & $2,179.30$ & TS & 01/10/2000 06:00 & 83 & 249.26 \\
\hline Chantal & TS & 14/08/2001 18:00 & $22 / 08 / 200106: 00$ & 111 & $6,103.02$ & TS & 19/08/2001 06:00 & 102 & 276.27 \\
\hline Isidore & H3 & 14/09/2002 18:00 & 27/09/2002 12:00 & 204 & $6,491.49$ & H3 & $21 / 09 / 2002$ 18:00 & 204 & 301.87 \\
\hline Bill & TS & 28/06/2003 06:00 & 02/07/2003 18:00 & 93 & $2,568.58$ & TD & $30 / 06 / 2003$ 12:00 & 37 & 210.71 \\
\hline Claudette & $\mathrm{Hl}$ & 07/07/2003 00:00 & $17 / 07 / 200306: 00$ & 139 & $6,369.85$ & TS & $15 / 07 / 200312: 00$ & 93 & 126.48 \\
\hline Larry & TS & 27/09/2003 18:00 & 07/10/2003 12:00 & 102 & $1,804.30$ & TD & 03/10/2003 00:00 & 37 & 303.85 \\
\hline Cindy & $\mathrm{Hl}$ & 03/07/2005 18:00 & $11 / 07 / 200500: 00$ & 120 & $4,948.72$ & TD & 06/07/2005 00:00 & 56 & 296.82 \\
\hline Emily & H5 & $11 / 07 / 200500: 00$ & $21 / 07 / 200506: 00$ & 259 & $6,594.79$ & $\mathrm{H} 4$ & 17/07/2005 00:00 & 278 & 209.40 \\
\hline Stan & $\mathrm{Hl}$ & 01/10/2005 12:00 & 05/10/2005 00:00 & 130 & $1,358.86$ & TS & 04/10/2005 12:00 & 74 & 323.03 \\
\hline Wilma & H5 & $15 / 10 / 200518: 00$ & 26/10/2005 12:00 & 296 & $5,668.83$ & $\mathrm{H} 4$ & $19 / 10 / 200512: 00$ & 222 & 99.99 \\
\hline Dean & H5 & 13/08/2007 06:00 & $22 / 08 / 2007$ 18:00 & 278 & $7,659.14$ & H5 & $21 / 08 / 200706: 00$ & 278 & 315.40 \\
\hline Olga & TS & $10 / 12 / 200712: 00$ & $16 / 12 / 200700: 00$ & 93 & $3,469.79$ & TD & 11/12/2007 18:00 & 56 & 63.49 \\
\hline Arthur & TS & 31/05/2008 00:00 & 01/06/2008 18:00 & 74 & 419.81 & TS & $31 / 05 / 2008$ 06:00 & 65 & 231.52 \\
\hline Dolly & $\mathrm{H} 2$ & 20/07/2008 12:00 & $26 / 07 / 2008$ 18:00 & 157 & $3,026.07$ & TS & $23 / 07 / 200812: 00$ & 83 & 175.76 \\
\hline Alex & $\mathrm{H} 2$ & 24/06/2010 18:00 & $01 / 07 / 201018: 00$ & 167 & $2,485.80$ & TS & 01/07/2010 00:00 & 102 & 212.34 \\
\hline Karl & H3 & 13/09/2010 18:00 & 18/09/2010 00:00 & 204 & $2,082.27$ & TS & 17/09/2010 12:00 & 102 & 303.62 \\
\hline Richard & $\mathrm{H} 2$ & 19/10/2010 18:00 & 26/10/2010 06:00 & 157 & $1,928.58$ & TS & 25/10/2010 00:00 & 74 & 57.57 \\
\hline Rina & TS & 22/10/2011 00:00 & 29/10/2011 18:00 & 185 & $1,633.80$ & TS & 28/10/2011 02:00 & 102 & 98.92 \\
\hline Ernesto & $\mathrm{H} 2$ & 01/08/2012 12:00 & 10/08/2012 01:00 & 157 & $5,585.08$ & $\mathrm{H} 2$ & 08/08/2012 00:00 & 157 & 342.30 \\
\hline Helene & TS & 09/08/2012 18:00 & 18/08/2012 18:00 & 74 & $6,420.32$ & TD & 16/08/2012 00:00 & 46 & 79.28 \\
\hline
\end{tabular}

where: Max. SS: Maximum Saffir-Simpson Hurricane Scale; UTC: Coordinated Universal Time; Max. Winds: Maximum sustained wind speed; and colors represent category on the Saffir-Simpson scale; TD: tropical depression, TS: tropical storm, H1-H5: Hurricane's category

Own elaboration

\subsection{Vegetation type classification}

Tropical forests are the predominant vegetation type in the entire region, covering more than three-quarters of the peninsula (78\%), followed by $9.6 \%$ grasslands, concentrated mainly in northern Yucatan State and some small areas in Campeche and southern Quintana Roo (Figure 3). Farming (cropland) land use accounts for 5\% of land cover, mainly near Yucatan and Campeche states and small areas in Quintana Roo's southern zone. Finally, hydrophilic vegetation covers $5.2 \%$ of the region, where it is distributed throughout the peninsula's coastal zone, from south of Quintana Roo in the Caribbean Sea, through northern Yucatan to south of Campeche. 


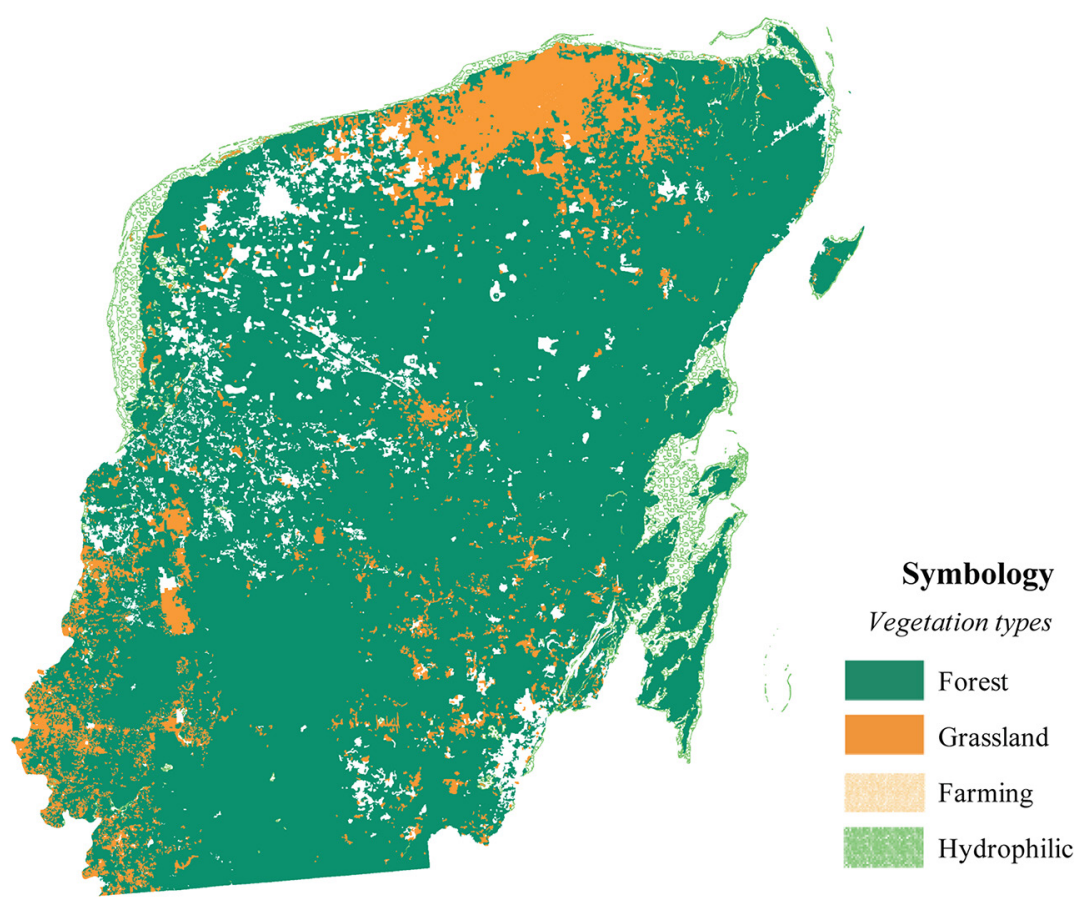

Own elaboration

\subsection{Impact zone}

The aNDVI values were statistically diluted, given the territorial extension of the areas directly impacted against the peninsula's surface not damaged by the winds and rains associated with the cyclones. Figure 4 shows an example of the NDVI and aNDVI values for hurricane Wilma (2005) during its track through the peninsula. Figure 5 shows the hurricane Wilma (2005) time series, wherein for the first composite (18-2005) before the presence of the hurricane, the aNDVI values were in the range of -1 to +1 - considered as a condition of normality-. The second image (19-2005), depicts the cyclone's landfall, during which the aNDVI increased dramatically toward the light and moderate deficit classes but only in a small area adjacent to its trajectory. It was approximately the fifth and sixth weeks (20-2005), after the cyclone had dissipated, that the most significant adverse effects on vegetation occurred with increases to a negative aNDVI, mainly toward the extreme deficit class.

Figure 4. Distribution of the mean values of a) NDVI and b) aNDVI for the composite corresponding to the passage of Hurricane Wilma (2005)

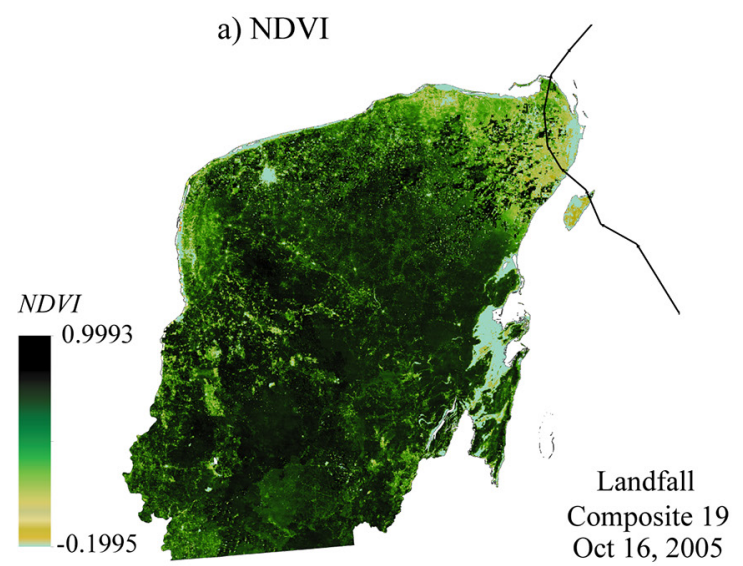

b) aNDVI
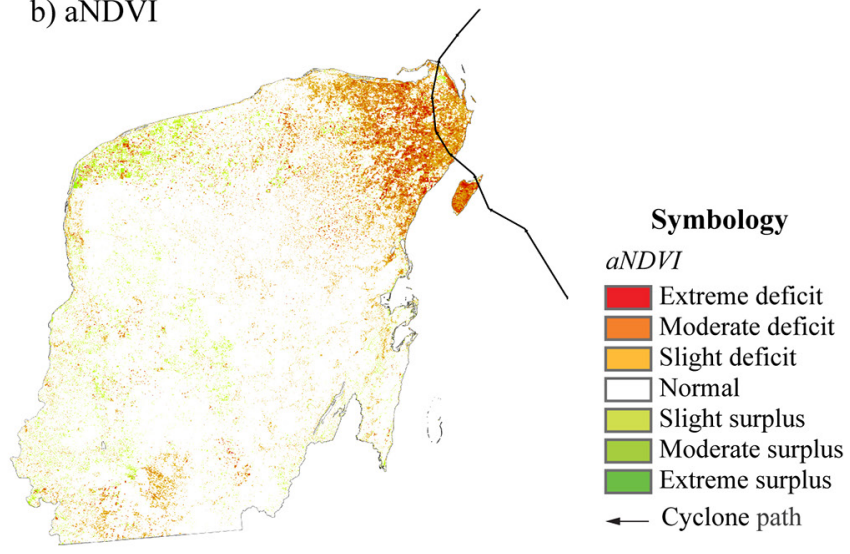

Own elaboration 
Figure 5. Distribution of mean aNDVI values by composite during Hurricane Wilma (2005)

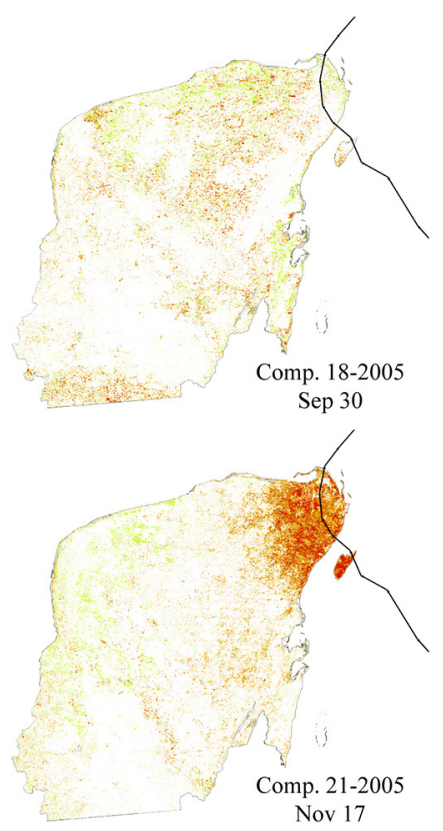

Nov 17

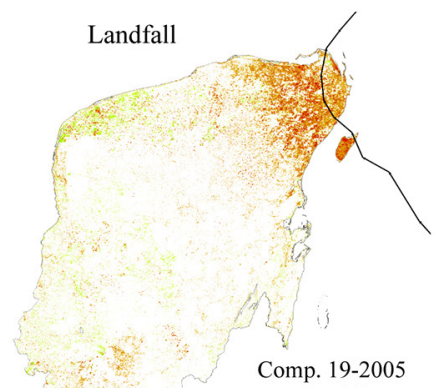

Oct 16

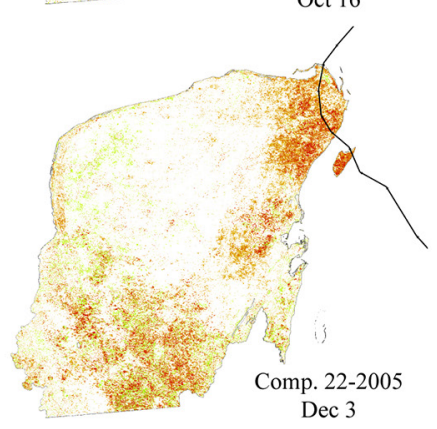

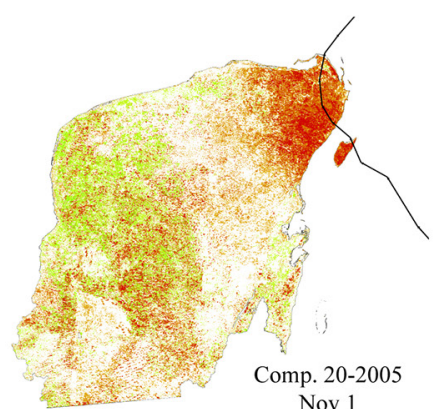

Nov 1

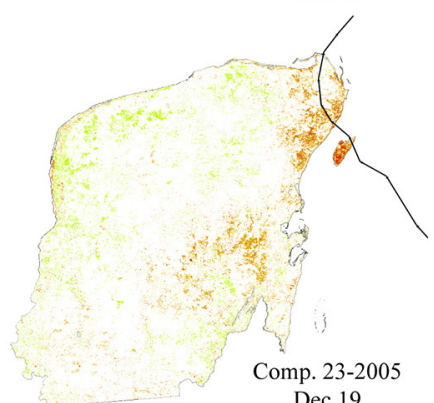

Dec 19

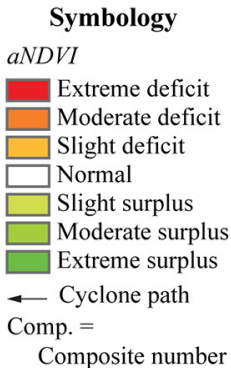

Own elaboration

Subsequently, the anomaly decreased remarkably close to the values before the cyclone track. Signs of recovery appeared between weeks 7 and 8 (23-2005). However, six weeks after the hurricane made landfall (22-2005), there was a slight uptick in the aNDVI values toward the moderate and extreme deficit classes on the south-southwest portion of the peninsula not directly associated with the passage of the cyclone. When calculated on a peninsular scale, such differences prevent the ability to accurately quantify the recovery rates of vegetation that suffered direct damage from cyclonic impacts.

In cases of very intense hurricanes such as Emily (2005, H4), Wilma (2005, H4), and Dean (2007, H5), the values did not decrease below 0.5 units (Figure 6). Furthermore, the existence of ascending and descending peaks in some aNDVI that did not correspond to the arrival of any cyclone could be the result of other types of extreme disturbances, such as drought, forest fires, El Niño-Southern Oscillation (ENSO), or land-use changes. Such is the case for composites 2-2005, 6-2009, and 8-2011. However, the explanation of such phenomena is outside the scope of this study.

Figure 6. Time series of aNDVI by 16-day composites on the Yucatan Peninsula

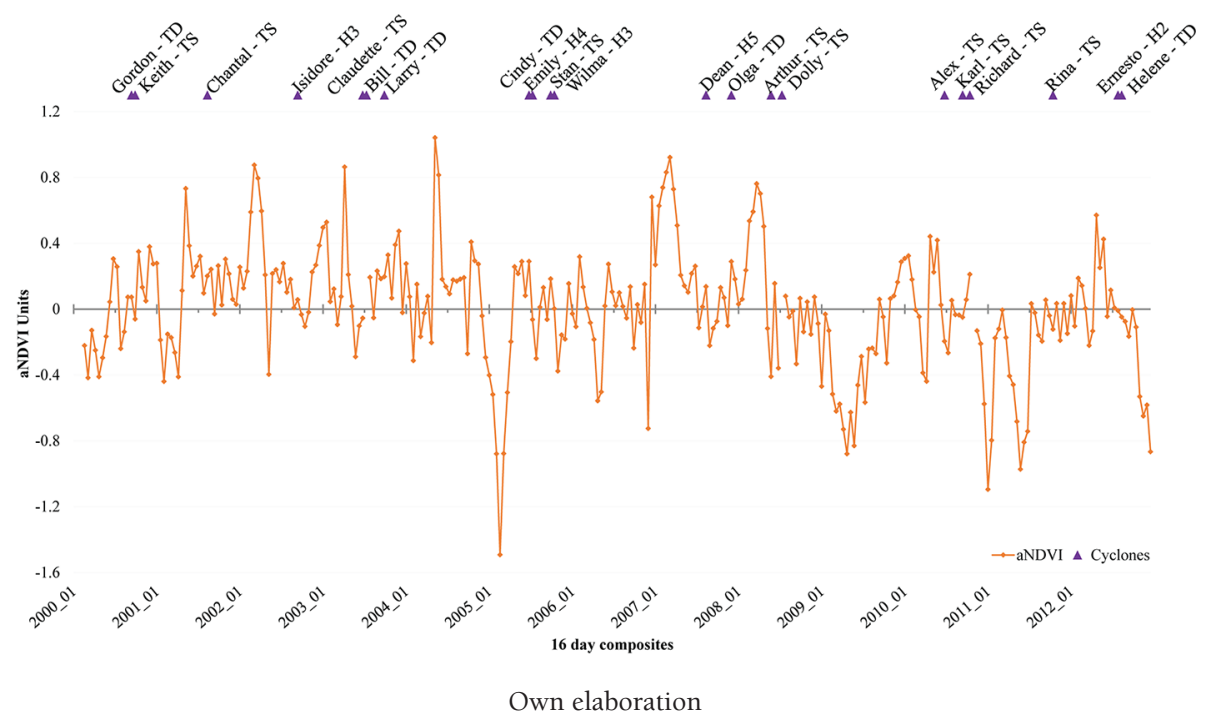


The effects of cyclonic tracks on vegetation greenery loss could not be determined using aNDVI values at the peninsula level. Based on the earlier results, the neighborhoods were delimited by each cyclonic event to isolate the areas damaged by precipitation and associated winds, which allowed the quantitative estimation of the vegetation's resilience in the face of such phenomena.

\subsection{Impact zones}

Cyclonic systems typically cross the peninsula in an east-west direction, either through the north or south, without showing a particular trend (Figure 7). That is, the number of cyclones that passed through the south was 9 in each case, except for three tropical depressions that crossed the peninsula diagonally, from southeast to northwest (Gordon, 2000; Bill, 2003 and Cindy, 2005). The distances traveled overland varied; the smallest corresponded to tropical storm Richard (2010), with $57.5 \mathrm{~km}$, and the maximum corresponded to hurricane Ernesto (2012, H2), with 342 km.

Figure 7. Distribution of aNDVI values, neighborhoods, and composites for hurricanes, tropical storms, and tropical depressions in the Yucatan Peninsula

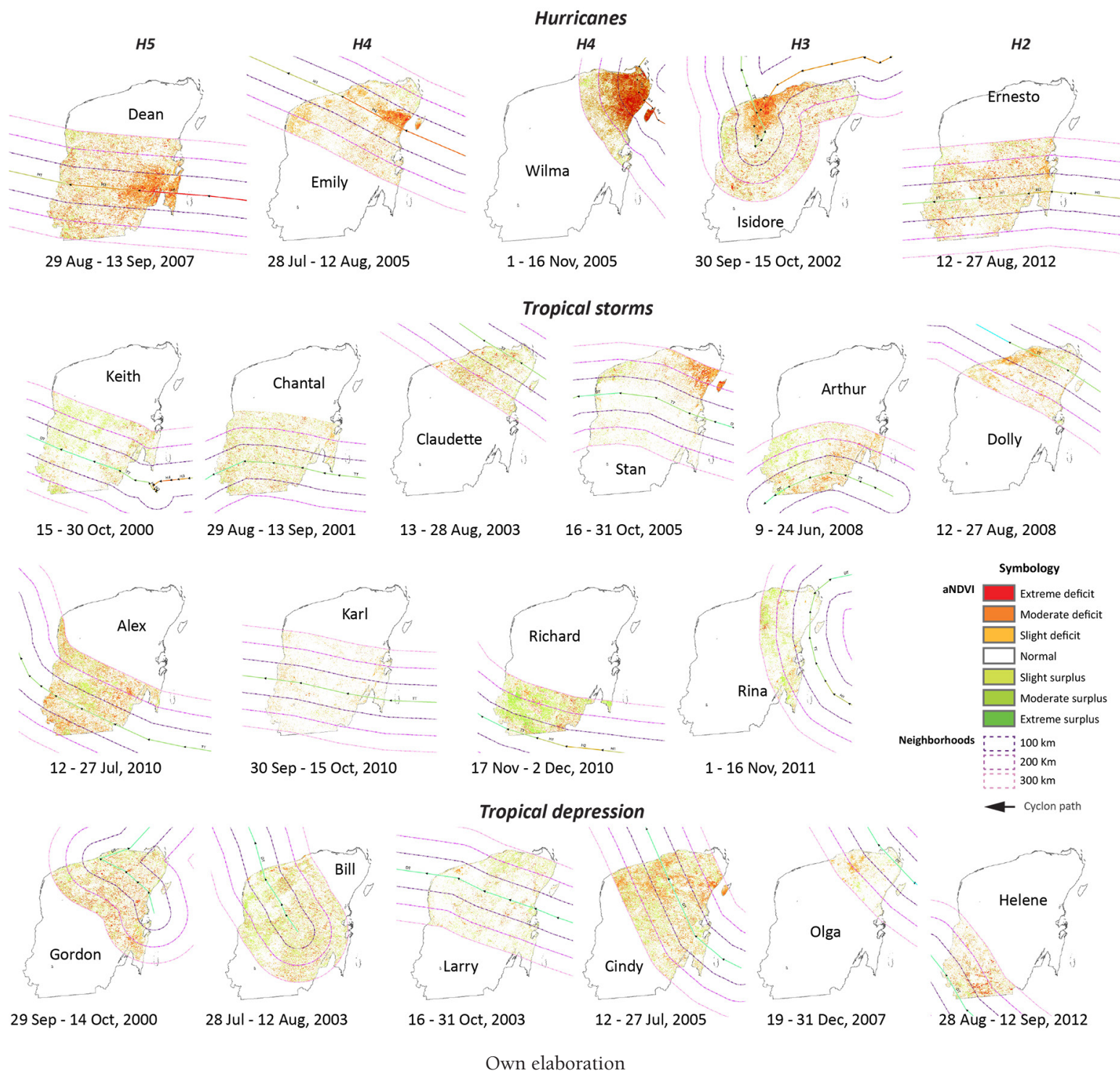

Of the five cyclones that made landfall in the Yucatan Peninsula in the hurricane category, three entered through the northeast (Isidore, 2002; Emily and Wilma, 2005), and two entered through the southeast (Dean, 2007 and Ernesto, 2012; Figure 7). Concerning the track length (total), Dean (2007) stands 
out with a maximum distance of $7,700 \mathrm{~km}$, and Ernesto (2012) stands out with a minimum_distance of $5,500 \mathrm{~km}$ (Table 2). Thus, Quintana Roo's state suffered the most considerable cyclonic disturbances, according to the aNDVI changes observed.

\subsection{Vegetation resilience to cyclonic impacts}

We classified the maximum damaged area and the recovery rates — resilience - into two groups (Table 3): a) those which had deficit values - loss of greenness - and b) those which favored photosynthetic activity — surplus-.

Table 3. Maximum coverage with extreme aNDVI values for each cyclone that made landfall in the Yucatan Peninsula (2000-2012): a) maximum aNDVI changes and maximum aNDVI increase rate (negative impact), b) minimum damaged areas, and maximum decrease rate recorded (positive impact)

a) Impact Type: Negative

\begin{tabular}{|c|c|c|c|c|c|c|c|c|c|c|}
\hline \multirow{3}{*}{ Cyclone } & \multirow{3}{*}{ Year } & \multicolumn{3}{|c|}{ Landfall } & \multirow{3}{*}{$\begin{array}{l}\text { Neighborhood } \\
\text { (Nh) with max. } \\
\text { Impact }\end{array}$} & \multirow{2}{*}{\multicolumn{2}{|c|}{$\begin{array}{c}\text { Maximum } \\
\text { damaged area } \\
\text { of } \mathrm{Nh}\end{array}$}} & \multirow{3}{*}{$\begin{array}{c}\text { Maximum } \\
\text { aNDVI }^{\text {increase }}{ }^{1} \\
{[\%]}\end{array}$} & \multicolumn{2}{|c|}{ Recovery $^{2}$} \\
\hline & & \multirow{2}{*}{$\begin{array}{l}\text { Max. } \\
\text { Saffir- } \\
\text { Simpson } \\
\text { Scale }\end{array}$} & \multirow{2}{*}{$\begin{array}{c}\text { Max. } \\
\text { Winds } \\
{[\mathrm{Km} / \mathrm{h}]}\end{array}$} & \multirow{2}{*}{$\begin{array}{l}\text { Track } \\
\text { length on } \\
\text { land }[\mathrm{km}]\end{array}$} & & & & & & \\
\hline & & & & & & $\%$ & $\mathrm{Km}^{2}$ & & [composites] & weeks \\
\hline Gordon & 2000 & TD & 46 & 275.15 & Nh-300 & 9.70 & $5,900.86$ & 5.24 & 1 & $2-3$ \\
\hline Keith & 2000 & TS & 83 & 249.26 & Nh-100 & 11.84 & $7,587.57$ & 1.82 & 1 & $2-3$ \\
\hline Isidore & 2002 & H3 & 204 & 301.87 & Nh-100 & 21.31 & $9,322.54$ & 14.66 & 1 & $2-3$ \\
\hline Bill & 2003 & TD & 37 & 210.71 & Nh-200 & 5.48 & $4,640.93$ & 1.84 & 2 & $4-5$ \\
\hline Claudette & 2003 & TS & 93 & 126.48 & Nh-200 & 6.63 & $2,230.85$ & 1.34 & $>6$ & $>13$ \\
\hline Cindy & 2005 & TD & 56 & 296.82 & Nh-100 & 11.22 & $8,260.82$ & 8.84 & 1 & $2-3$ \\
\hline Emily & 2005 & $\mathrm{H} 4$ & 278 & 209.40 & Nh-100 & 15.50 & $7,766.06$ & 12.80 & 4 & $9-10$ \\
\hline Wilma & 2005 & $\mathrm{H} 4$ & 222 & 99.99 & Nh-100 & 72.54 & $9,368.73$ & 69.07 & 1 & $2-3$ \\
\hline Dean & 2007 & H5 & 278 & 315.40 & Nh-100 & 21.29 & $12,363.62$ & 16.17 & 1 & $2-3$ \\
\hline Arthur & 2008 & TS & 65 & 231.52 & Nh-300 & 11.63 & $6,313.37$ & 9.39 & 1 & $2-3$ \\
\hline Alex & 2010 & TS & 102 & 212.34 & Nh-100 & 14.13 & $6,905.24$ & 6.59 & 2 & $4-5$ \\
\hline Richard & 2010 & TS & 74 & 57.57 & Nh-100 & 5.56 & $1,782.54$ & 4.88 & 2 & $4-5$ \\
\hline Ernesto & 2012 & $\mathrm{H} 2$ & 157 & 342.30 & Nh-200 & 7.75 & $5,631.27$ & 2.20 & 1 & $2-3$ \\
\hline Helene & 2012 & TD & 46 & 79.28 & Nh-100 & 9.15 & $2,223.45$ & 4.58 & 2 & $4-5$ \\
\hline
\end{tabular}

b) Impact Type: Positive

\begin{tabular}{|c|c|c|c|c|c|c|c|c|c|c|}
\hline \multirow{3}{*}{ Cyclone } & \multirow{3}{*}{ Year } & \multicolumn{3}{|c|}{ Landfall } & \multirow{3}{*}{$\begin{array}{l}\text { Neighborhood } \\
\text { (Nh) with max. } \\
\text { Impact }\end{array}$} & \multirow{2}{*}{\multicolumn{2}{|c|}{$\begin{array}{c}\text { Maximum } \\
\text { damaged area } \\
\text { of } \mathrm{Nh}\end{array}$}} & \multirow{3}{*}{$\begin{array}{c}\text { Maximum } \\
\text { aNDVI } \\
\text { decrease }^{3} \\
{[\%]}\end{array}$} & \multicolumn{2}{|c|}{ Recovery ${ }^{4}$} \\
\hline & & \multirow{2}{*}{$\begin{array}{l}\text { Max. } \\
\text { Saffir- } \\
\text { Simpson } \\
\text { Scale }\end{array}$} & \multirow{2}{*}{$\begin{array}{c}\text { Max. } \\
\text { Winds } \\
{[\mathrm{Km} / \mathrm{h}]}\end{array}$} & \multirow{2}{*}{$\begin{array}{l}\text { Track } \\
\text { length on } \\
\text { land }[\mathrm{km}]\end{array}$} & & & & & & Anproximate \\
\hline & & & & & & $\%$ & $\mathrm{Km}^{2}$ & & [composites] & weeks \\
\hline Chantal & 2001 & TS & 102 & 276.27 & Nh-100 & 5.33 & $3,362.42$ & -2.98 & 2 & $4-5$ \\
\hline Larry & 2003 & TD & 37 & 303.85 & Nh-100 & 7.94 & $5,576.64$ & -0.30 & 2 & $4-5$ \\
\hline Stan & 2005 & TS & 74 & 323.03 & Nh-300 & 3.78 & $3,364.85$ & -4.73 & 2 & $4-5$ \\
\hline Olga & 2007 & TD & 56 & 63.49 & Nh-200 & 2.73 & 570.45 & -6.28 & 2 & $4-5$ \\
\hline Dolly & 2008 & TS & 83 & 175.76 & Nh-300 & 4.31 & $1,867.79$ & -2.80 & 2 & $4-5$ \\
\hline Karl & 2010 & TS & 102 & 303.62 & Nh-300 & 8.29 & $6,740.53$ & -0.18 & 2 & $4-5$ \\
\hline Rina & 2011 & TS & 102 & 98.92 & Nh-100 & 4.16 & $1,127.46$ & -1.17 & 2 & $4-5$ \\
\hline
\end{tabular}

1. Maximum percentage increase in aNDVI by composite before cyclone landfall.

2. Return to aNDVI before the cyclone makes landfall.

3. Maximum decline of aNDVI before the cyclone landfall.

4. Time-lapse to get the minimum aNDVI.

Where colors represent categories on the Saffir-Simpson scale; TD: tropical depression, TS: tropical storm, H1-H5: Hurricane's category. 
Seven cyclones (33.3\%) that reached the tropical depression or tropical storm categories caused an immediate increase in photosynthetic activity. Such were the cases of Karl (2010), Rina (2011), and Larry (2003), when after 2 or 4 weeks, the aNDVI reached levels higher than those before the cyclones had landfall (Figure 8).

Figure 8. Temporal variations in the mean values of the aNDVI by type of vegetation and neighborhood: a) Karl (2010),

b) Rina (2011), and c) Larry (2003). The aNDVI changes were calculated from the earlier composite,

up to four subsequent composites. The second composite in each time series graph represents the crossing of the cyclone. Composite 20-2010 were reported as missing
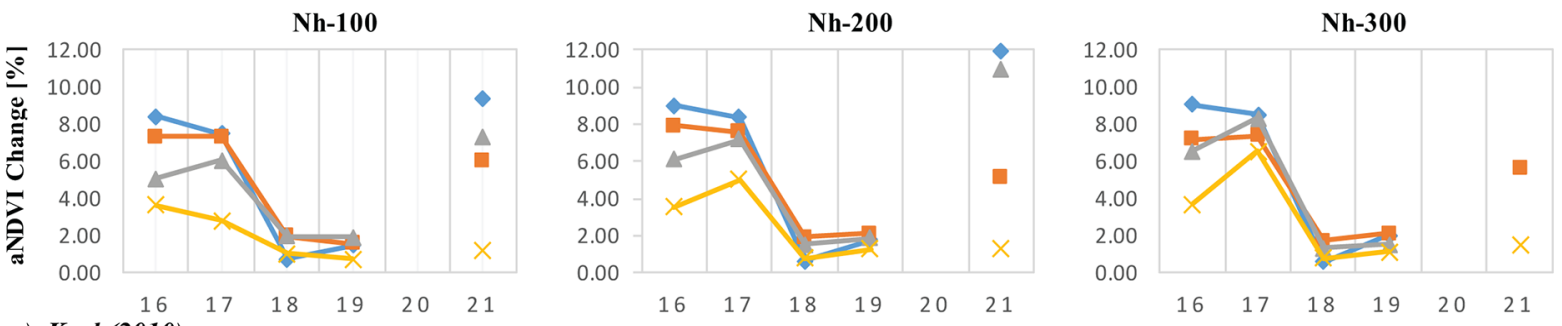

a) Karl (2010)
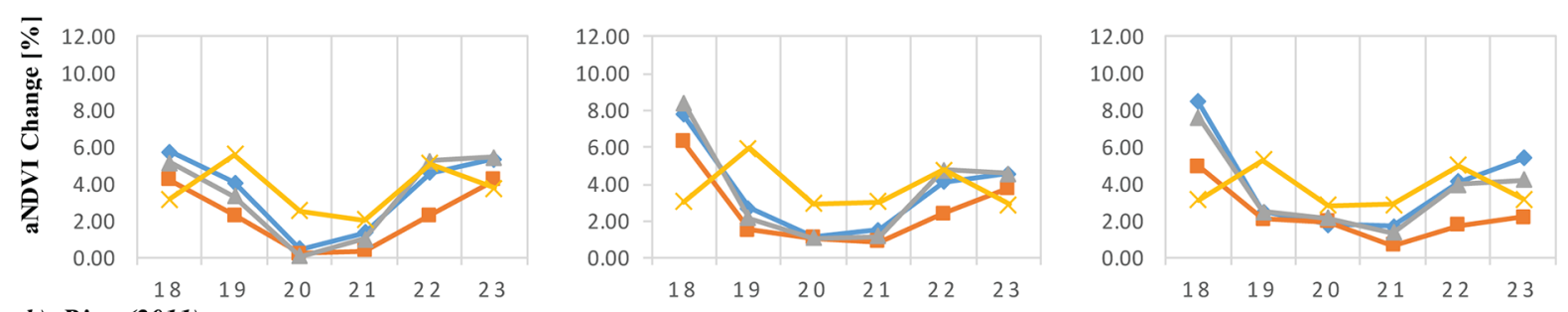

b) Rina (2011)
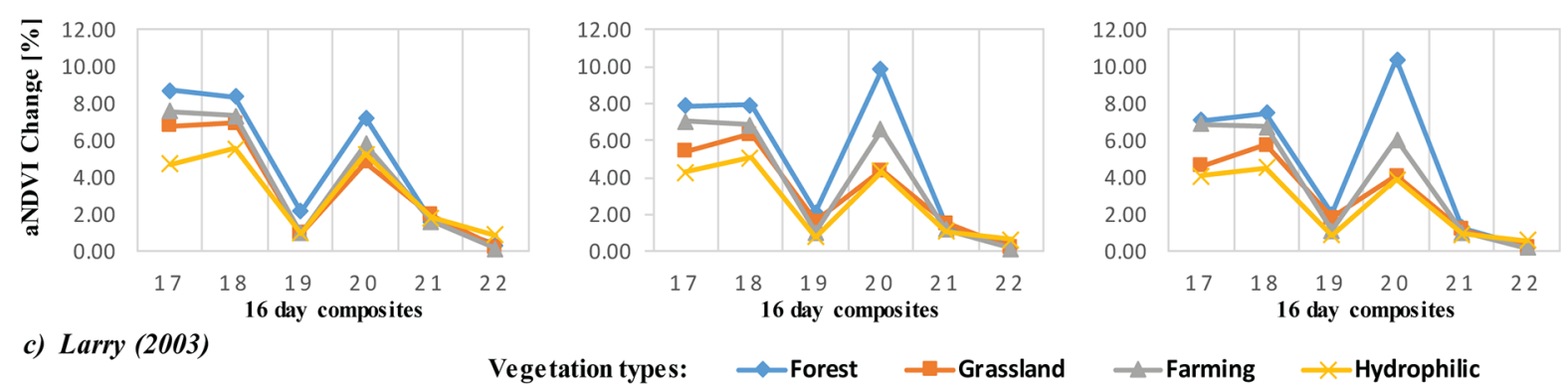

Own elaboration

Tropical forests suffered the most significant damage from cyclones. In nine of the 14 cases (64\%), negative aNDVI was observed. Hydrophilic vegetation was also damaged negatively in five cases (36\%). In 11 cases (52\%), recovery needed four to five weeks; that is, the aNDVI values returned to extremely close levels before the cyclone landfall at a lapse rate. In 38\% of the cases, the recovery lapses were 2 or 3 weeks. The case of hurricane Wilma (2005) stands out; its damages were the most extreme, with 70\% negative impacts. The most prolonged recovery corresponded to Hurricane Emily (2005) and tropical storm Claudette (2003). It took more than ten weeks in the case of Hurricane Emily, while after Claudette, it took more than thirteen weeks (Figure 9).

The impact of cyclones on vegetation was classified based on the maximum differences in aNDVI values, and as time passed, the aNDVI returned to precyclone levels. The results by category are as follows:

- Negative impacts: 67\% (14 cyclones)

- Little significant impact: in ten cases, the differences in the aNDVI did not stand for an increase of more than $10 \%$, most of them corresponding to depressions and tropical storms, except for hurricane Ernesto (2012, H2).

- Moderate impact: three of the hurricanes had an aNDVI increase on the order of 10 to 20\%: Isidore (2002, H3), Emily (2005, H4), and Dean (2007, H5). 
- Extreme impact: Wilma (2005, H4) was the only hurricane with differences in aNDVI values of close to $70 \%$.

- Positive impacts: $33 \%$ (7 cyclones).

- No one event in this class reached the hurricane category on the Saffir-Simpson scale.

- The maximum difference in the aNDVI was close to $6 \%$ in the case of tropical depression Olga (2007).

Figure 9. Temporal behavior of the mean values of the aNDVI based on a type of vegetation and neighborhood: a) Wilma (2005), b) Emily (2005), and c) Claudette (2003). The changes in aNDVI were calculated from the earlier up to four subsequent composites after the cyclone's landfall. The second composite in each time series graph marks the passage of the cyclone. Composite 13-2003 was reported as missing
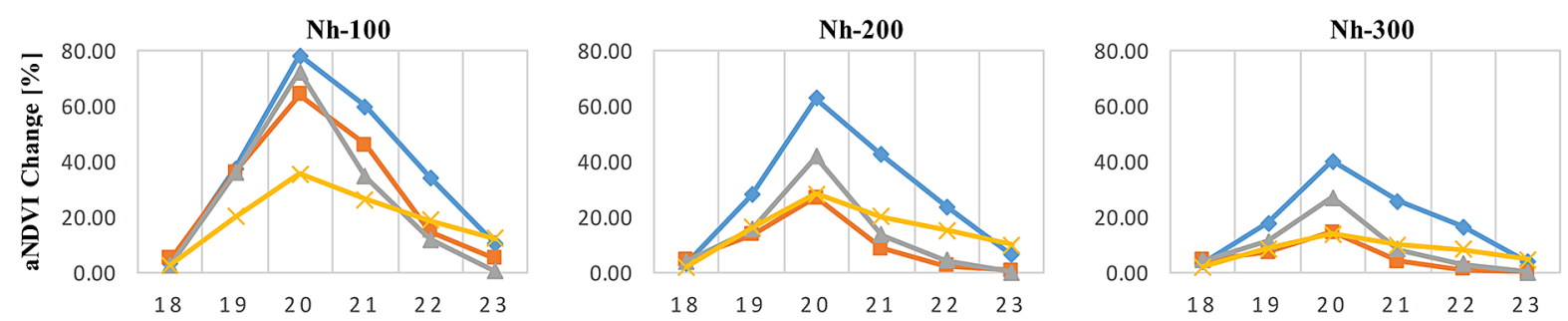

a) Wilma (2005)
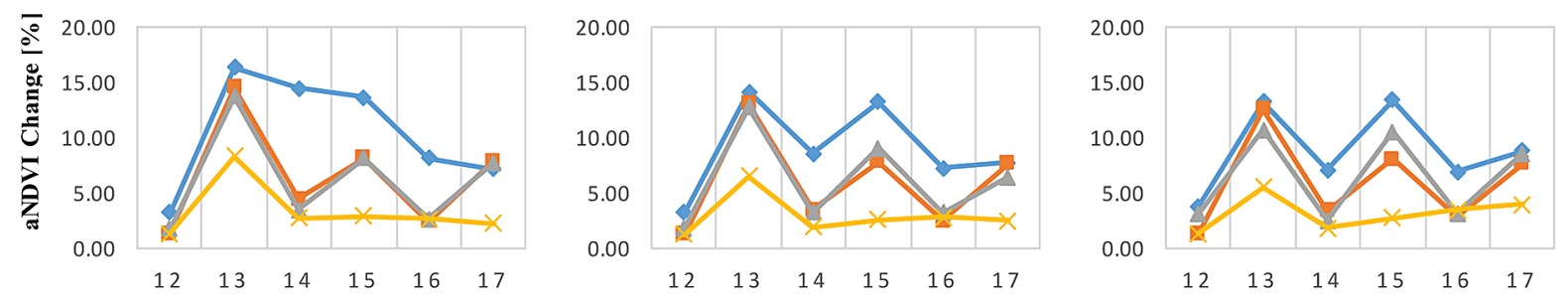

b) Emily (2005)

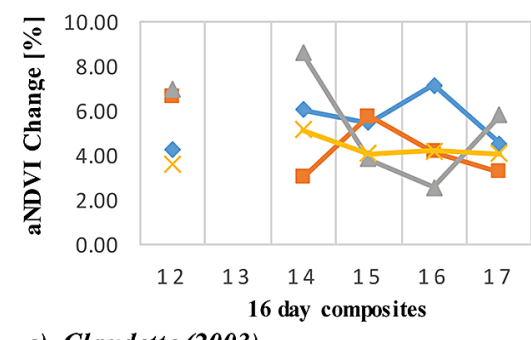

c) Claudette (2003)

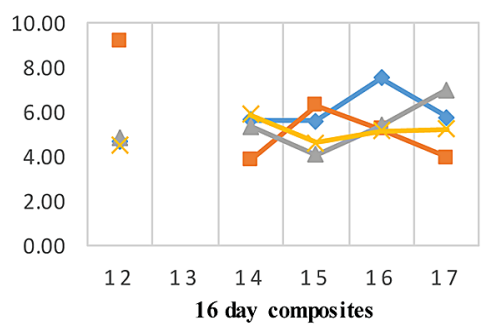

egetation types:
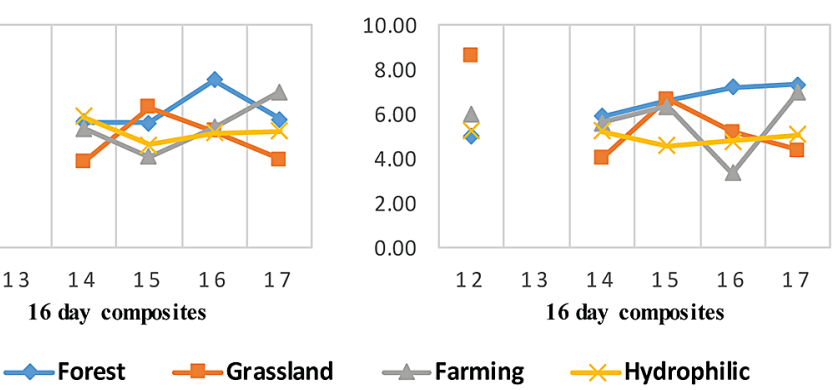

$\leadsto$ Farming $\quad$ Hydrophilic

Own elaboration

\subsection{Comparative statistical analysis}

The multiple correlations showed a highly significant relationship between the impacted area and aNDVI $\left(R^{2}=0.99\right)$; the greater the area impacted, the more significant the decrease in NDVI values. A moderately significant relationship between the cyclonic categories and the aNDVI was obtained $\left(R^{2}=0.63\right)$. A higher intensity of sustained winds was found in $60 \%$ of cases; the damaged area was higher, and the aNDVI differences were more significant. In contrast, there was not a correlation between the cyclone categories and the length of their tracks overland $\left(\mathrm{R}^{2}=0.16\right)$ and with the recovery interval of the aNDVI $\left(R^{2}=-0.07\right)$, and between the distance traveled and the maximum damaged area $\left(R^{2}=-0.12\right)$ and the difference in the aNDVI $\left(\mathrm{R}^{2}=-0.17\right)$. This pattern is likely due to the fact that the cyclone tracks crossed the mainland very near the coast but did not make landfall. The results of the correlations between the maximum damaged area and the difference in the aNDVI are consistent with those obtained through linear regression (Pearson $\mathrm{R}^{2}=0.97$ ), which indicates a directly proportional relationship between the maximum impacted area and the difference in the aNDVI (Figure 10). 
Figure 10. Linear correlations between the maximum damaged area, maximum sustained winds, and distance traveled by cyclone vs. aNDVI values before the cyclone's landfall
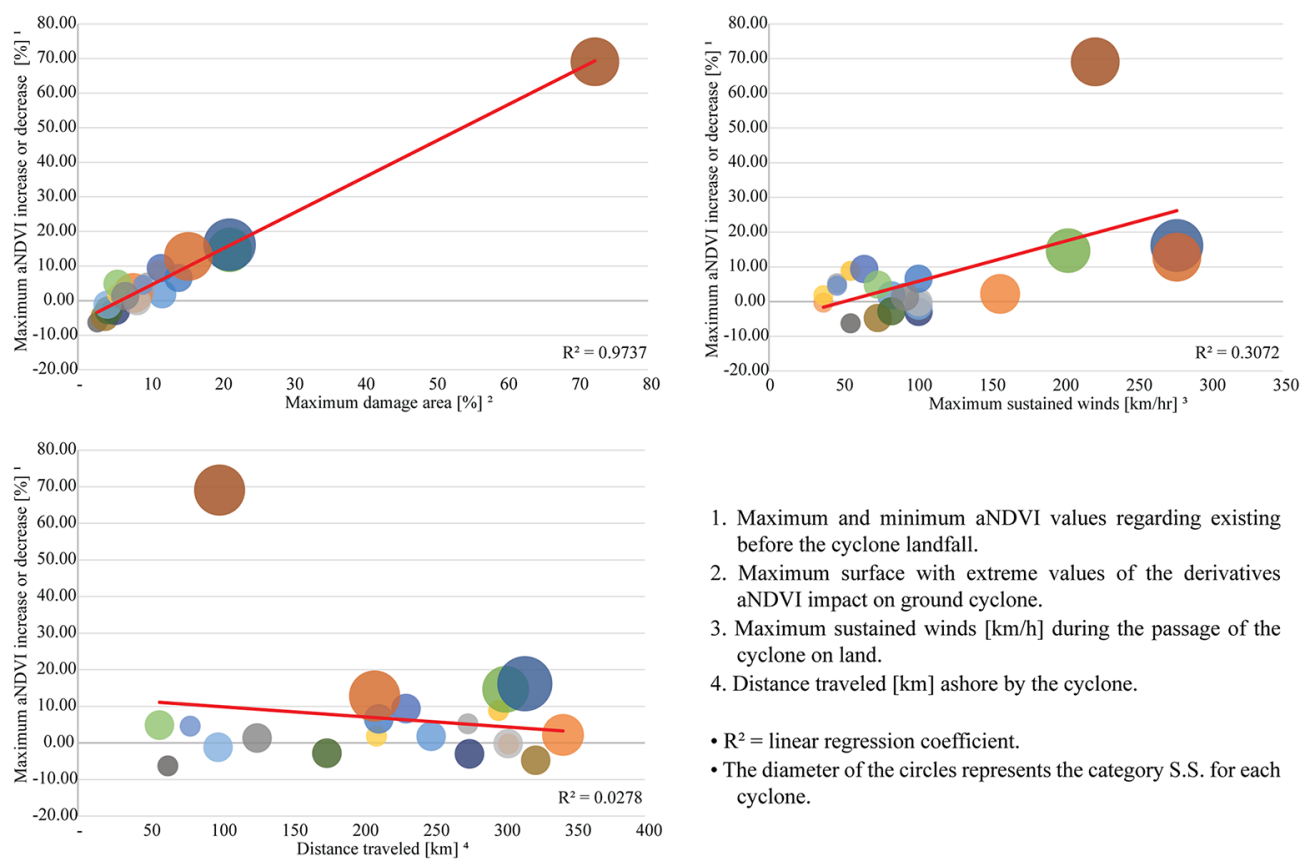

1. Maximum and minimum aNDVI values regarding existing before the cyclone landfall.

2. Maximum surface with extreme values of the derivatives aNDVI impact on ground cyclone.

3. Maximum sustained winds $[\mathrm{km} / \mathrm{h}]$ during the passage of the cyclone on land.

4. Distance traveled $[\mathrm{km}]$ ashore by the cyclone.

- $\mathrm{R}^{2}=$ linear regression coefficient

- The diameter of the circles represents the category S.S. for each cyclone.

Own elaboration

\section{Discussion}

Resilience is a recurrent concept in different fields and disciplines, which has led to the formulation of various definitions of the term (Hosseini, Barker, \& Ramirez-Marquez, 2016). To study the resilience and adaptation of natural systems, the ecological resilience definition proposed by Holling (1996) is still valid. Resilience estimations can be quantitative or qualitative (Wang, Nistor, \& Pickl, 2017). For the present study, the change in photosynthetic activity, measured through aNDVI, was assumed to be a quantitative indicator of vegetation recovery capacity. We found that vegetation recovery rates -resilience- after a cyclone crossing took an average of 8 to 9 weeks for the Yucatan Peninsula. Tropical forest covers approximately $78 \%$ of the peninsula's surface and shows greenery recovery in periods less than 8 to 9 weeks after high-intensity hurricanes cross the region. In contrast, low-intensity hurricanes presented decreases in the values of the aNDVI in percentages of less than $10 \%$ of the surface with recovery rates between 2 and 4 weeks. Seven of the cyclones identified as tropical depression and tropical storm categories damaged the vegetation but also allowed for rapid regeneration.

The two most intense cyclones in the Yucatan Peninsula from 2000 to 2012 were Wilma (2005) and Dean (2007). The first reached the peninsula near Quintana Roo state, in an area known as the "Riviera Maya." Some of the most significant land-use changes have occurred in this area due to tourist activities and urbanization. Wilma wreaked havoc in the cities of Cozumel, Playa del Carmen, and Cancun. Among the damages are the destruction of plant communities and urban systems, which means significant economic losses for the region (Zenteno Casas, Avelar Frausto, \& Reinoso Angulo, 2006 and Rivera-Monroy et al., 2020). The second case was hurricane Dean (2007), which made landfall in the southwestern part of Quintana Roo and led to the highest number of uprooted and broken trees (Navarro-Martínez, Durán-García, \& Méndez-González, 2012). Mangrove and medium-stature forests in Mahahual were defoliated to varying degrees; however, within a month, the medium-stature forest had recovered - foliation- by nearly $80 \%$ (Islebe, Torrescano-Valle, Valdez-Hernández, Tuz-Novelo, \& Weissenberger, 2009). In previous work, Sánchez \& Islebe (1999) emphasized that mangroves begin to recover after five to seven months. Although our findings were based on remote sensing products, the vegetation types damaged by cyclonic activity coincide with those reported in the literature.

Some studies on resilience to cyclones have covered the Mexican Pacific coast. Bhaskar et al. (2018) researched the resilience of the dry forest to the impact of Hurricane Jova (2011, H2) in the Chamela- 
Cuixmala Biosphere Reserve in the state of Jalisco, Mexico. Their results revealed a decrease in the total basal area. The most frequent damage is uprooted trees and the loss of small branches. This is why the most dense vegetation, such as mangroves and tropical forests, must be conserved and protected against illegal logging.

As in the case of the dry forest of the Chamela-Cuixmala Biosphere Reserve, along the coast of the Mexican Pacific and the Gulf of Mexico, different types of forest ecosystems exposed to the impact of tropical cyclones exist (Rosengaus-Moshinsky, Jiménez-Espinosa, \& Vázquez-Conde, 2002; INEGI, 2017), where the resistance and resilience capacities could be estimated by implementing the methodology presented in this study.

\section{Conclusions}

A methodology based on remote sensing products and techniques, combined with vegetation indexes, such as the NDVI and the aNDVI, allowed us to estimate the impacted areas and vegetation resilience capacity between a period of less than 8 and 9 weeks after each of 21 registered tropical cyclones that hit the Yucatan Peninsula between 2000 and 2012.

This study shows that satellite images and the green index are helpful for detecting areas where the vegetation status or conditions after the cyclone impact require priority attention and fieldwork and studies to identify the exact causes of the minimum recovery rates. The techniques used made it possible to identify relationships between each cyclone's impacts given their trajectory, category, and permanence by neighborhood.

The rapid recovery of photosynthetic activity following the passage of tropical cyclones suggests that the vegetation on the peninsula is well adapted to the interaction with such hydrometeorological phenomena. However, of the 21 cyclones analyzed only in those cases considered extreme events in terms of their wind intensity and inland permanency, the vegetation suffered severe damage that required long periods for their recovery.

Although the effects of high-intensity tropical cyclone landfall on vegetation have already been reported in the scientific literature, the study results allow us to compare the resilience capacity differences between four types of vegetation against the impact of cyclones of varying intensities. Our findings could contribute to assessing the vulnerability of the peninsula's vegetation to severe hydrometeorological events and establishing priority areas for their prompt inspection and, where appropriate, designing and carrying out more detailed and higher-scale studies in specific areas.

These research findings can also help to estimate recovery costs, apply conservation measures, and sustainably manage farming and ecotouristic locations in the region. Likewise, they allow the ranking of the areas with the most significant impacts, easing the establishment and delimitation of regions or priority areas for their attention.

To advance the understanding and knowledge of the processes of adaptation and recovery of the peninsula's forest ecosystems, investigations must be conducted that consider the effects caused not only by a single phenomenon and in isolation but also by the integration of multiple natural and extreme anthropogenic events at different spatiotemporal scales. This could also be considered to design different uses and management schemes that identify the effects and responses based on the four types of vegetation present in the region.

Finally, we propose to consider other resilience models, such as those based on a bivariate approach of resistance and resilience applied under a framework of spatial analysis techniques. Adding additional analysis variables, such as precipitation volumes and the flood zones associated with each cyclone studied, would allow future studies to better estimate the intrinsic attributes and extrinsic environmental factors for an ecological unit from observing long-term state changes.

\section{Funding}

The author thanked the National Autonomous University of Mexico, the Faculty of Philosophy and Letters, and Postgraduate in Geography for the scholarship granted to carry out the Master of Geography studies, as well as to the University of Quintana Roo, the Observation Laboratory and Space Research, the Sustainable Development Division and CONACYT, for the scholarship granted (597620) to carry out doctoral studies in Sustainable Development in the Cozumel Academic Unit. 


\section{References}

Aboud, S. R., Bias, E. S., Brites, R. S., \& Santos, C. A. M. (2018). Multitemporal Change Detection Using the NDVI Model in the Soil Use and Land Cover. Anuário do Instituto de Geociências - UFRJ, 41(3), 592-604. https://doi.org/10.11137/2018_3_592_604

Bhaskar, R., Arreola, F., Mora, F., Martinez-Yrizar, A., Martinez-Ramos, M., \& Balvanera, P. (2018). Response diversity and resilience to extreme events in tropical dry secondary forests. Forest Ecology and Management, 426(June 2017), 61-71. https://doi.org/10.1016/j.foreco.2017.09.028

Boose, E. R., Foster, D. R., \& Hall, B. (2003). Geographical and Historical Variation in Hurricanes Across the Yucatán Peninsula. En A. Gomez-Pompa, M.F. Allen, S.L. Fedick, J.J. Jimenez-Osornio (Edit.), The lowland Maya area: three millennia at the human-wildland interface (pp. 495-516). Binghamton, NY: Haworth Press. Retrieved from https://www.researchgate.net/profile/Brian-Hall-13/ publication/268260749_Geographical_and_Historical_Variation_in_Hurricanes_Across_the Yucatan_Peninsula/links/5739cfa408ae9ace840dblfa/Geographical-and-Historical-Variation-inHurricanes-Across-the-Yucatan-Peninsula.pdf

Buma, B., \& Wessman, C. A. (2011). Disturbance interactions can impact resilience mechanisms of forests. Ecosphere, 2(5), 1-13. https://doi.org/10.1890/ES11-00038.1

Ghazoul, J., \& Chazdon, R. L. (2017). Degradation and Recovery in Changing Forest Landscapes: A Multiscale Conceptual Framework. Annual Review of Environment and Resources, 42(1), 161-188. https://doi.org/10.1146/annurev-environ-102016-060736

Gómez-Mendoza, L. (2007). Variabilidad Climática y cambio de uso del suelo en la Sierra Norte de Oaxaca: implicaciones en los escenarios de cambio climático (Tesis doctoral). Universidad Nacional Autonoma de México. Retrieved from http://ru.atheneadigital.filos.unam.mx/jspui/handle/FFYL UNAM/5044_TD168? mode $=$ simple

Holling, C. S. (1996). Engineering Resilience versus Ecological Resilience. In National Academy of Engineering. Engineering Within Ecological Constraints. Washington, DC: The National Academies Press. https://doi.org/10.17226/4919

Holm, J. A., Van Bloem, S. J., Larocque, G. R., \& Shugart, H. H. (2017). Shifts in biomass and productivity for a subtropical dry forest in response to simulated elevated hurricane disturbances. Environmental Research Letters, 12(2), 13. https://doi.org/10.1088/1748-9326/aa583c

Hosseini, S., Barker, K., \& Ramirez-Marquez, J. E. (2016). A review of definitions and measures of system resilience. Reliability Engineering and System Safety, 145, 47-61. https://doi.org/10.1016/j. ress.2015.08.006

Huete, A., Didan, K., Miura, T., Rodriguez, E. P., Gao, X., \& Ferreira, L. G. (2002). Overview of the radiometric and biophysical performance of the MODIS vegetation indices. Remote Sensing of Environment, 83(1-2), 195-213. https://doi.org/10.1016/S0034-4257(02)00096-2

IBTrACS. (2016). IBTrACS v03r09 - Online browsing. International Best Track Archive for Climate Stewardship (IBTrACS). NOAA. Retrieved from https://www.ncdc.noaa.gov/ibtracs/index. php?name=ib-v3-access

Ihl, T., \& Frausto-Martínez, O. (2014). El Cambio Climático y los huracanes en la Península de Yucatán. En O. Frausto Martínez (Coord.), Monitoreo de riesgo y desastre asociados a fenómenos hidrometeorológicos y cambio climático (pp. 42-49). Universidad de Quintana Roo - REDESClim - CONACYT. Retrieved from https://www.mendeley.com/catalogue/monitoreo-riesgo-y-desastre-asociados-fenómenoshidrometeorológicos-y-cambio-climático/

INEGI. (2001). Conjunto de datos vectoriales Fisiográficos. Continuo Nacional escala 1:1 000000 serie I (Provincias fisiográficas). s.l. Instituto Nacional de estadística, Geografía e Informática. Retrieved from https://www.inegi.org.mx/temas/fisiografia/

INEGI. (2017). Cuarenta años de cartografía de la vegetación de México. Información de Uso del Suelo y Vegetación serie VI. In Instituto Nacional de Estadística y Geografía. Información de Uso del Suelo y Vegetación serie VI. Retrived from https://www.snieg.mx/DocumentacionPortal/geografico/sesiones/ doc_22017/Present_Serie_VI_Carta_U_Sue.pdf 
INEGI. (2009). Uso del suelo y vegetación, escala 1:250,000, serie IV (Continuo Nacional), escala: 1:250000. Dirección General de Geografía. Instituto Nacional de Estadística y Geografía. Instituto Nacional de Estadística y Geografía. Retrieved from https://www.inegi.org.mx/temas/usosuelo/default. $\underline{\text { html\#Mapa }}$

IRI. (2017). USGS LandDAAC MODIS version_005 Southern North America. Retrieved from http://iridl. ldeo.columbia.edu/SOURCES/.USGS/.LandDAAC/.MODIS/.version_005/.SNA/.NDVI/

IRI, UNESCO, FAO, Ministerio de Agrícultura de Chile \& Centro del Agua para Zonas Aridas (2021). Climate Data Library. Retrived from https://www.climatedatalibrary.cl/maproom/Monitoring/NDVI/ NDVI.html? Set-Language $=$ en\#tabs-1

Islebe, G., Torrescano-Valle, N., Valdez-Hernández, M., Tuz-Novelo, M., \& Weissenberger, H. (2009). Efectos del impacto del huracán Dean en la vegetación del sureste de Quintana Roo, México. Foresta Veracruzana, 11(1), 1-6. Retrived from https://www.redalyc.org/pdf/497/49711999001.pdf

Jimenez-Rodríguez, D. L., Alvarez-Añorve, M. Y., Flores-Puerto, J. I., Oyama, K., Avila-Cabadilla, L. D., Pineda-Cortes, M., \& Benítez-Malvido, J. (2018). Structural and functional traits predict short term response of tropical dry forests to a high intensity hurricane. Forest Ecology and Management, 426(April), 101-114. https://doi.org/10.1016/j.foreco.2018.04.009

Martínez-Yrízar, A., Jaramillo, V. J., Maass, M., Búrquez, A., Parker, G., Álvarez-Yépiz, J. C., ... \& Sarukhán, J. (2018). Resilience of tropical dry forest productivity to two hurricanes of different intensity in western Mexico. Forest Ecology and Management, 426(February), 53-60. https://doi.org/10.1016/j. foreco.2018.02.024

Meroni, M., Fasbender, D., Rembold, F., Atzberger, C., \& Klisch, A. (2019). Near real-time vegetation anomaly detection with MODIS NDVI: Timeliness vs. accuracy and effect of anomaly computation options. Remote Sensing of Environment, 221(February), 508-521. https://doi.org/10.1016/j. rse.2018.11.041

Nanzad, L., Zhang, J., Tuvdendorj, B., Nabil, M., Zhang, S., \& Bai, Y. (2019). NDVI anomaly for drought monitoring and its correlation with climate factors over Mongolia from 2000 to 2016. Journal of Arid Environments, 164(February), 69-77. https://doi.org/10.1016/j.jaridenv.2019.01.019

Navarro-Martínez, A., Durán-García, R., \& Méndez-González, M. (2012). El impacto del huracán Dean sobre la estructura y composición arbórea de un bosque manejado en Quintana Roo, México. Madera y Bosques, 18(1), 57-76. https://doi.org/10.21829/myb.2012.1811138

NHC. (2019). Glossary of NHC Terms. Centro Nacional de Huracanes de los Estados Unidos de América. Retrieved from https://www.nhc.noaa.gov/aboutgloss.shtml

NOAA. (2014). Preguntas frecuentes, versión 4.7. Hurricane Reseach Division. Retrieved from https://www. aoml.noaa.gov/hrd/tcfaq/tcfaqHED_esp.html

Oliver, T. H., Heard, M. S., Isaac, N. J. B. B., Roy, D. B., Procter, D., Eigenbrod, F., ... \& Bullock, J. M. (2016). A Synthesis is Emerging between Biodiversity-Ecosystem Function and Ecological Resilience Research: Reply to Mori. Trends in Ecology and Evolution, 31(2), 89-92. https://doi.org/10.1016/j. tree.2015.12.008

Parker, G., Martínez-Yrízar, A., Álvarez-Yépiz, J. C., Maass, M., \& Araiza, S. (2018). Effects of hurricane disturbance on a tropical dry forest canopy in western Mexico. Forest Ecology and Management, 426(December 2017), 39-52. https://doi.org/10.1016/j.foreco.2017.11.037

Rebollar, S., De la Paz-Pérez Olvera, C., \& Quintanar, A. (1993). Anatomía de la madera de cinco especies de Quintana Roo, México. Boletín de la Sociedad Botánica de México, 53, 113-124. https://doi. org/10.17129/botsci.1418

Rivera-Monroy, V. H., Farfán, L. M., Brito-Castillo, L., Cortés-Ramos, J., González-Rodríguez, E., D’Sa, E. J., \& Euan-Avila, J. I. (2020). Tropical cyclone landfall frequency and large-scale environmental impacts along Karstic Coastal Regions (Yucatan Peninsula, Mexico). Applied Sciences (Switzerland), 10(17). https://doi.org/10.3390/app10175815

Rosengaus-Moshinsky, M. (2010). Impacto de los ciclones tropicales en las cuencas de México. En H. Cotler-Ávalos (Coord.), Las cuencas hidrográficas de México: Diagnóstico y priorización (pp. 32-37). Retrieved from https://agua.org.mx/biblioteca/las-cuencas-hidrograficas-de-mexico-diagnostico-ypriorizacion 
Rosengaus-Moshinsky, M., Jiménez-Espinosa, M., \& Vázquez-Conde, M. T. (2002). Atlas Climatológico de Ciclones Tropicales en México. Retrieved from http://www.cenapred.gob.mx/es/Publicaciones/ archivos/37.pdf

Rouse, J. W., Haas, R. H., Schell, J. A., \& Deering, D. W. (1973). Monitoring the vernal advancement and retrogradation (green wave effect) of natural vegetation. Type II Preliminary. En Progress Report RSC 1978-1. Retrieved from https://ntrs.nasa.gov/archive/nasa/casi.ntrs.nasa.gov/19730017588.pdf

Sánchez Aguilar, R. L., \& Rebollar Domínguez, S. (2016). Deforestación en la Península de Yucatán, los retos que enfrentar. Madera y Bosques, 5(2), 3. https://doi.org/10.21829/myb.1999.521344

Sánchez Sánchez, O., \& Islebe, G. A. (1999). Hurricane Gilbert and structural changes in a tropical forest in south-eastern Mexico. Global Ecology and Biogeography, 8(1), 29-38. https://doi.org/10.1046/ j.1365-2699.1999.00317.x

Snook, Laura. (1993). Stand Dynamics of Mahogany (Swietenia macrophylla King) and Associated Species after Fire and Hurricane in the Tropical Forests of the Yucatan Peninsula, Mexico (Ph.D. Tesis). Yale University. https://doi.org/10.13140/RG.2.2.25237.35045

Solow, A. R. (2017). On detecting ecological impacts of extreme climate events and why it matters. Philosophical Transactions of the Royal Society B: Biological Sciences, 372(1723), 8-11. https://doi. org/10.1098/rstb.2016.0136

Tapia-Palacios, M. A., García-Suárez, O., Sotomayor-Bonilla, J., Silva-Magaña, M. A., Pérez-Ortíz, G., Espinosa-García, A. C., ... \& Mazari-Hiriart, M. (2018). Abiotic and biotic changes at the basin scale in a tropical dry forest landscape after Hurricanes Jova and Patricia in Jalisco, Mexico. Forest Ecology and Management, 426(May 2017), 18-26. https://doi.org/10.1016/j.foreco.2017.10.015

Van de Pol, M., Jenouvrier, S., Cornelissen, J. H. C., \& Visser, M. E. (2017). Behavioural, ecological and evolutionary responses to extreme climatic events. Philosophical Transactions of the Royal Society B, 372(1723), 20160372. https://doi.org/10.1098/rstb.2016.0134

Vink, K., \& Ahsan, M. N. (2018). The benefits of cyclones: A valuation approach considering ecosystem services. Ecological Indicators, 95(February), 260-269. https://doi.org/10.1016/j.ecolind.2018.07.035

Wang, Z., Nistor, M. S., \& Pickl, S. W. (2017). Analysis of the Definitions of Resilience. IFAC-PapersOnLine, 50(1), 10649-10657. https://doi.org/10.1016/j.ifacol.2017.08.1756

Wilks, D. S. (2011). Statistical Methods in the Atmospheric Sciences (Third ed.). Elsevier Science. Retrieved from https://www.elsevier.com/books/statistical-methods-in-the-atmospheric-sciences/ wilks/978-0-12-385022-5

Yengoh, G. T., Dent, D., Olsson, L., Tengberg, A. E., Tucker, C. J., \& Tucker III, C. J. (2016). Use of the Normalized Difference Vegetation Index (NDVI) to Assess Land Degradation at Multiple Scales: Current Status, Future Trends, and Practical Considerations. En Lund University Center for Sustainability Studies (LUCSUS), and The Scientific and Technical Advisory Panel of the Global Environment Facility (STAP/GEF). Springer International Publishing. https://doi.org/10.1007/978-3-319-24112-8

Zenteno Casas, M., Avelar Frausto, C. E., \& Reinoso Angulo, E. (2006). Estadísticas de los daños por viento causados a las estructuras por el huracán Wilma en el Caribe Mexicano. XV Congreso Nacional de Ingeniería Estructural, 19. Retrieved from https://www.smie.org.mx/eventos/memorias/index. php? avanzada $=0 \&$ where- $0=$ autor\&keyword- $0=$ Mauricio + Zenteno+Casas

Zewdie, W., \& Csaplovics, E. (2015). Evaluation of rainfall and NDVI anomalies using distributed lag models. En M. Velez-Reyes \& F. A. Kruse (Eds.), Algorithms and Technologies for Multispectral, Hyperspectral, and Ultraspectral Imagery XXI (Vol. 9472, Número Dl, p. 94721O). https://doi. org/10.1117/12.2176803 